\title{
Bonds convertible to raw materials in the context of bonds convertible to shares and ordinary bonds
}

\author{
Robert Ranosz ${ }^{1, a}$ \\ ${ }^{1}$ AGH University, Department of Economics and Management in Industry, Al. Mickiewicza 30 30-059 Kraków, Poland
}

\begin{abstract}
This article presents an analysis of bonds convertible to raw materials in the context of ordinary bonds and bonds convertible to shares. The author of the publication decided to explore what kind of benefits an enterprise issuing bonds and a bondholder would receive as exemplified by a hypothetical investment, using various (aforementioned) sources of foreign capital. The article is composed of four parts. The introduction hereto outlines some general assumptions and the purpose of the study. The second part of the article includes the assumptions for the aforementioned comparative analysis. It was suggested that since such variables as the price of raw materials, shares and operating costs of a company are difficult to determine, they should be distributed so that on the basis thereof the final NPV may be established by applying the Monte Carlo method. The third part of the study focuses on the examination (comparison) of the bonds convertible to raw materials in the context of ordinary bonds and bonds convertible to shares. The result of such an analysis is the NPV histogram for particular sources of financing, a probability distribution defining the probability of occurring individual NPV values. The last part constitutes a summary of the entire study.
\end{abstract}

\section{Introduction}

The financing of mining investments is one of the most important financial problems faced by the Polish mining industry. Among the tools for financing investments are bonds, which have been used more frequently in the last few years by both Polish and foreign mining companies. Their success results mainly from their flexibility and the relatively low cost of the capital. Due to their high popularity the corporate bond market is developing, and hence new options may be embedded. The additional options lower the cost of the said bonds, in contrast with other bonds without such options. The most popular options embedded in bonds include a possibility of changing (converting) debts to shares. The author of this publication deliberates on bonds convertible to raw materials. It is assumed that this solution retains the features of every convertible bond, and thus lowers the interest on the debt security compared to a regular corporate bond $[1,2]$. The purpose of this article is to compare the bonds convertible to raw materials with ordinary bonds and bonds convertible to shares in the context of benefits derived by both the issuer and bondholder. As illustrated by the calculation example, it was assumed that a mining company shall be the bond issuer and an electric power company the bondholder.

\section{Initial assumptions for the analysis}

The efficiency of investment is significant not only for the investor, but also the company using the capital. The investment is more profitable if the return generated thereon is higher. One of the most frequently used methods for estimating the efficiency of the investment is the NPV (Net Present Value) based on the discounted cash flows. The NPV is influenced by many factors, such as: the forecast sales price, forecast level of costs, structure and cost of the capital, and source of the capital. This article focuses on the last of the above-mentioned factors. Due to the nature of this publication, it was decided to analyse only corporate bonds. Coupon bonds, convertible bonds and bonds convertible to raw materials were taken into consideration for the purpose of this analysis. To obtain the most reliable results possible, the Monte Carlo method was applied. Therefore, the result of the analysis shall be the expected NPV (E(NPV)).

Due to the fact that the market price of raw material, price of share, and level of operating costs may be subject to changes in the period of the analysis, and that the length of such a period is difficult to predict, the analysis was performed using the Monte Carlo method. To conduct the analysis correctly, it is crucial to first determine its input parameters (table 1). In the performed study, the distribution of random factors was also assumed

\footnotetext{
a Corresponding author: rranosz@agh.edu.pl
} 
(table 2). In the case of the price of raw material and price of share, it was assumed that the probability distribution is the regular distribution, where such parameters as the expected value and standard deviation [3] shall be established, whereas in the case of the operating costs, it was assumed that it is the triangular distribution, where the minimum, maximum and most probable values [4] need to be determined. Furthermore, it was decided that the bondholder shall convert debt into raw material at the time when the market price of the raw material becomes profitable, and hence at the time when the market price of the raw material exceeds the conversion price increased by the amount of the lost profits in the form of the interest. The bondholder shall always convert half of the debt. A similar assumption was made regarding bonds convertible to shares. However, in such a case, the amount of the lost profits was not included. It was also decided that the bondholder shall not sell the acquired shares and shall derive profits from the dividend due there to $[5,6]$.

Table 1. Initial assumptions for the calculation example

\begin{tabular}{|c|c|c|}
\hline Variable & Unit & Value \\
\hline Forecast period & {$[$ years] } & 7 \\
\hline Nominal value of a bond & {$[\mathrm{PLN}]$} & 100 \\
\hline Number of issued bonds & {$[\mathrm{pcs}]$} & 20,000 \\
\hline Conversion factor* & & 0.5 \\
\hline Initial price per share & {$[\mathrm{PLN}]$} & 230 \\
\hline $\begin{array}{c}\text { Initial market price per raw } \\
\text { material }\end{array}$ & {$[\mathrm{PLN} / \mathrm{Mg}]$} & 230 \\
\hline Initial operating cost & {$[\mathrm{PLN} / \mathrm{Mg}]$} & 170 \\
\hline Interest rates on bonds & {$[\%]$} & 5 \\
\hline Income tax & {$[\%]$} & 19 \\
\hline Own (capital) contribution & {$[$ ths. PLN] } & 200,000 \\
\hline Raised capital & {$[$ ths. PLN] } & 200,000 \\
\hline WACC & {$[\%]$} & 8.5 \\
\hline
\end{tabular}

*bonds convertible to raw materials and shares

Source: author's own study

Table 2. Parameters defining the distribution of the adopted variables

\begin{tabular}{|c|c|c|c|c|}
\hline Variable & $\begin{array}{c}\text { Type of } \\
\text { distribution }\end{array}$ & \multicolumn{3}{|c|}{ Parameters defining the distribution } \\
\hline & & \multicolumn{2}{|c|}{ Expected value } & $\begin{array}{l}\text { Standard } \\
\text { deviation }\end{array}$ \\
\hline $\begin{array}{l}\text { Change of } \\
\text { the price } \\
\text { per raw } \\
\text { material }\end{array}$ & Normal & \multicolumn{2}{|c|}{$26 \%$} & $41 \%$ \\
\hline & & \multicolumn{2}{|c|}{ Expected value } & $\begin{array}{l}\text { Standard } \\
\text { deviation }\end{array}$ \\
\hline $\begin{array}{l}\text { Change of } \\
\text { the price }\end{array}$ & Normal & \multicolumn{2}{|c|}{$81 \%$} & $94 \%$ \\
\hline & & Minimum & $\begin{array}{l}\text { Most } \\
\text { probable }\end{array}$ & Maximum \\
\hline $\begin{array}{c}\text { Change of } \\
\text { operating } \\
\text { costs }\end{array}$ & triangular & $-21.2 \%$ & $16.1 \%$ & $90.7 \%$ \\
\hline
\end{tabular}

On the basis of the adopted assumptions (table 1), a comparison between individual sources of financing was made (bonds convertible to raw materials, ordinary bonds, and bonds convertible to shares) in the context of benefits obtained by the parties to a contract (the bondholder and the mining company). On the basis of the calculation example, it was also decided that in the case of financing investments through bonds convertible to raw materials, the bondholder (a power plant) shall sign a contract with the mining company for the delivery of raw materials, and thus, in the event that the debt is converted into a raw material, the bondholder shall - in exchange for reducing the debt - receive a part of the said delivery (conversion factor* the amount of the converted bonds) "for free".

\section{Analysis of efficiency of investments using various types of bonds}

Within the framework of the analysis performed using the Monte Carlo method, 1170 drawings were made in accordance with the assumptions described in the previous chapter.

In the first step, the benefits that the mining company may obtain were analysed. The result of this analysis is the NPV histogram for particular types of bonds (figure 1) and expected values (table 3 ). To better illustrate the differences between the examined sources of financing, the probability distribution was also provided to show the possibility of reaching the NPV within the individual divisions (figure 2).

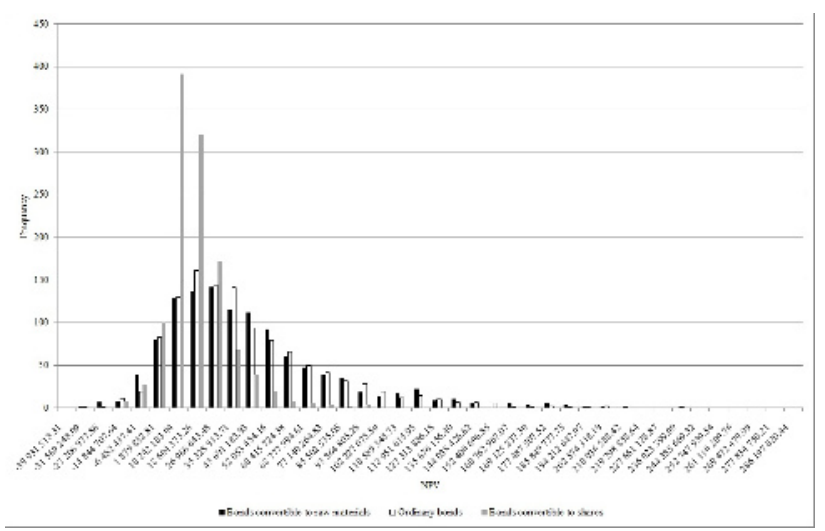

Figure 1. NPV histogram for particular types of bonds (for the bond issuer)

Source: author's own study

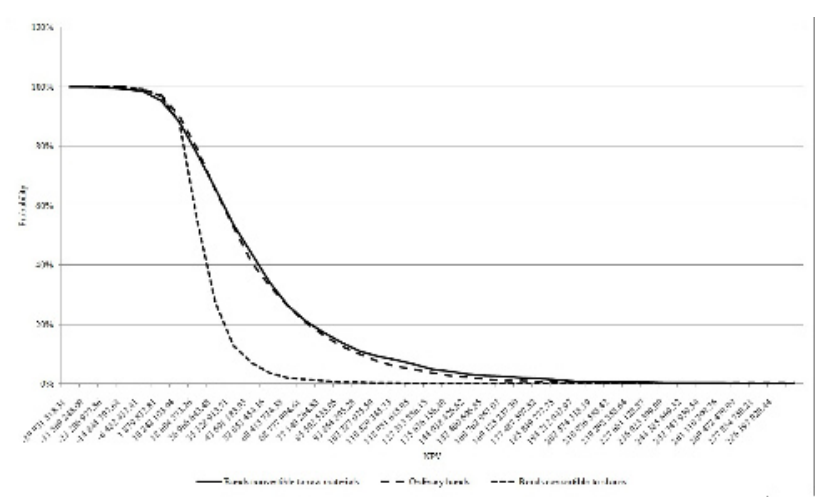

Figure 2. Probability distribution for the NPV depending on the source of financing (for the bond issuer)

Source: author's own study 
Table 3. Expected value of cash flows (for the bond issuer) for particular sources of foreign capital

\begin{tabular}{l|c|c|}
\hline Type of bond & Unit & E(NPV) \\
\hline Ordinary bonds & [ths. PLN] & $41,343,675.99$ \\
\hline $\begin{array}{l}\text { Bonds convertible to raw } \\
\text { materials }\end{array}$ & [ths. PLN] & $43,312,380.24$ \\
\hline $\begin{array}{l}\text { Bonds convertible to } \\
\text { shares }\end{array}$ & [ths. PLN] & $18,289,894.72$ \\
\hline
\end{tabular}

On the basis of the analysis, it is evident that from the point of view of the bond issuer the most beneficial source of financing for the adopted assumptions shall be the bonds convertible to raw materials used to finance investments. Financing through ordinary bonds is also a good solution, whereas the use of the bonds convertible to shares is definitely the least advantageous. According to figure 2, the probability that the investment value exceeds PLN 43 million in the case of such bonds is nearly $0 \%$, whereas in the case of the ordinary bonds and bonds convertible to raw materials it is almost $40 \%$. The result obtained for the last of the above-mentioned sources of financing mining investments is the least beneficial, mostly due to the fact that the bonds held by the bondholder are converted into the equity of the company, and thus the weighted average cost of the capital of the investment undertaken is increased. Since the bondholder becomes a shareholder in the mining company, it is also entitled to a dividend, i.e. a share in profits, and thus the mining company shall be obliged to allocate some part of its profits for the payment of such a dividend to the bond acquirer.

The issuer of debt securities is not the only entity deciding about the choice of the foreign capital. The decision is also to be made by the bondholder. The aim of such foreign capital shall be to mitigate the risk and maximise the profit. Depending on the bond type, the profits shall be at different levels. In the case of bonds convertible to raw materials, the bondholder shall derive profits, apart from the received interest, with the possibility of a debt-to-raw material conversion at a fixed conversion price, which allows the bondholder to purchase the raw material at a price lower than the settlement price effective at a given time. In the case of bonds convertible to shares, apart from the interest at the time of the debt-to-share conversion, the investor shall also derive profits from the dividend due thereto. In the case of ordinary bonds, the bondholder shall derive profits from the interest. As in the case of the bond issuer, the particular sources of financing have been compared. The result of this analysis is the NPV histogram for particular types of bonds (figure 3 ) and expected values (table 4). To better illustrate the differences between the examined sources of financing, the probability distribution was also provided to show the possibility of reaching the NPV within the individual divisions (figure 4).

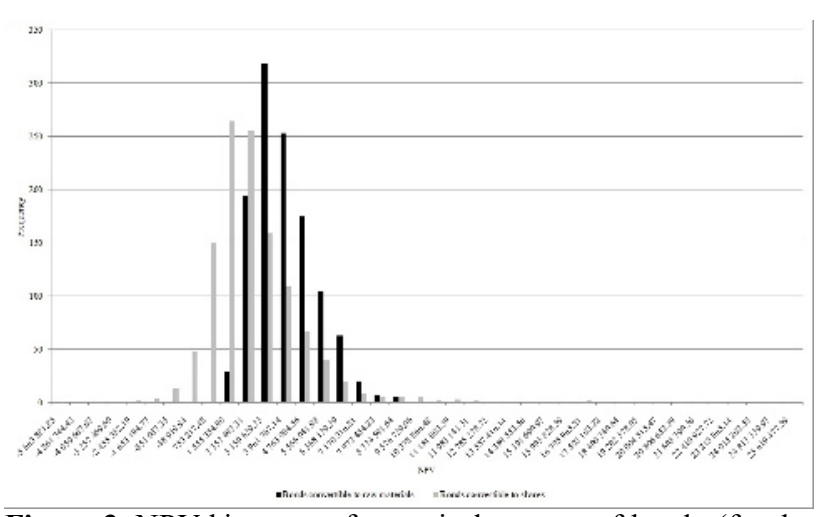

Figure 3. NPV histogram for particular types of bonds (for the bondholder)

Source: author's own study

The histogram presented in figure 3 does not include ordinary bonds due to the fact that in this case the bondholder shall benefit from the amount of the interest obtained for the investment period, which is not subject to change.

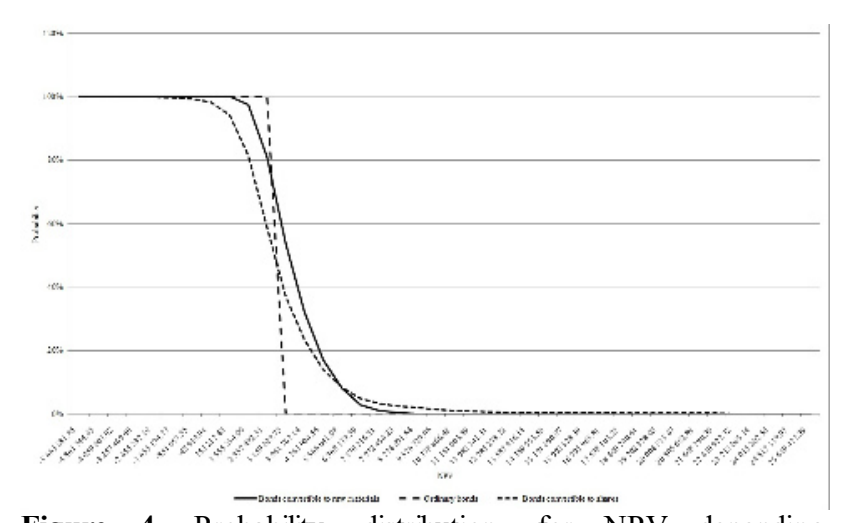

Figure 4. Probability distribution for NPV depending on the source of financing (for the bondholder)

Source: author's own study

Table 4. Expected value of cash flows (for the bondholder) for particular sources of foreign capital

\begin{tabular}{|l|c|c|}
\hline Type of bond & Unit & E(NPV) \\
\hline Ordinary bonds & [ths. PLN] & $2,357,492.31$ \\
\hline $\begin{array}{l}\text { Bonds convertible to raw } \\
\text { materials }\end{array}$ & [ths. PLN] & $3,910,348.08$ \\
\hline $\begin{array}{l}\text { Bonds convertible to } \\
\text { shares }\end{array}$ & [ths. PLN] & $2,626,284.44$ \\
\hline
\end{tabular}

Source: author's own study

The results of the analysis explicitly show that from the point of view of the bondholder bonds convertible to raw materials are the most beneficial type of bond. The second choice would be bonds convertible to shares. Ordinary bonds are the least beneficial solution. In such a case, the bondholder derives profits from the interest on the loan capital only. At this point, it should be stressed that ordinary bonds do not provide the investor with any additional option in connection with the above (among those listed); ordinary bonds pose the highest risk to the investor. 


\section{Summary}

This article was aimed at comparing three sources of capital in the form of bonds convertible to raw materials, bonds convertible to shares, and ordinary corporate bonds. On the basis of the obtained results, bonds convertible to raw materials are the most beneficial type of bonds for the mining company from the point of view of the expected value of the discounted cash flows received based on the Monte Carlo method, whereas bonds convertible to shares are the least beneficial solution. The situation changes when the investment is considered from the point of view of the bondholder. In this case, bonds convertible to raw materials are the most advantageous solution, then bonds convertible to shares, and finally ordinary bonds as the worst solution.

\section{Bibliography}

1. F.J. Fabozzi, Rynki obligacji analiza i strategie. (Wydawnictwo Fiansnowe WIG-PRESS, Warsaw, 2000)

2. E.F. Brigham \& J.F.Houston, Podstawy zarządzania finansami 1. (Polskie Wydawnictwo Ekonomiczne Warsaw, 2005)

3. W.Dębski, Rachunek efektywności inwestycji. (Oficyna a Wolters Kluwer business. Kraków, 2008)

4. P.Kosowski, Metody oceny efektywności ekonomicznej podziemnego magazynu gazu. (Rozprawa doktorska Akademia GórniczoHutnicza im. Stanisława Staszica w Krakowie Wydział Wiertnictwa Nafty i Gazu. Kraków, 2008)

5. W.Dębski, Rynek finansowy i jego mechanizmy. (Wydawnictwo Naukowe PWN, Warsaw, 2010).

6. A.Rutkowski, Zarządzanie finansami. (PWE, Warsaw, 2007) 